\title{
Surface carbohydrates and cell wall structure of in vitro-induced uredospore infection structures of Uromyces viciae-fabae before and after treatment with enzymes and alkali
}

\author{
S. Freytag** and K. Mendgen* \\ Phytopathologie, Fakultät für Biologie, Universität Konstanz, Konstanz \\ Received July 7, 1990 \\ Accepted September 3, 1990
}

\begin{abstract}
Summary. Uredospores of Uromyces viciae-fabae differentiate to form germ tubes, appressoria, infection hyphae and haustorial mother cells on oil-containing collodion membranes. The cell walls of these infection structures were studied with the electron microscope and with FITC-labeled lectins before and after treatment with enzymes and inorganic solvents. Binding of the FITC-labeled lectins was measured with a microscope photometer. The enzymes pronase E, laminarinase, chitinase and lipase had different effects on each infection structure. Pronase treatment uncovered the chitin of germ tubes, appressoria and haustorial mother cells, but not of substomatal vesicles and infection hyphae. A mixture of $\alpha$ - and $\beta-1,3-$ glucanase which also contained chitinase activity dissolved germ tubes and appressoria completely, but not infection pegs, substomatal vesicles, infection hyphae and haustorial mother cells. After treatment with laminarinase or lipase, an additional layer, which is especially obvious over the substomatal vesicle, infection hypha and haustorial mother cell, bound to LCA-FITC. In the wall of the haustorial mother cell, a ring, which surrounds the presumed infection peg, had strong affinity for WGA after protease and sodium hydroxide treatment. The infection structures have a fibrillar skeleton. The main constituent seems to be chitin. This skeleton is more dense or has a higher chitin content in the walls of appressoria and haustorial mother cells. The fibrils of the skeleton extend throughout the cell wall of the germ tube and appressorium. They are embedded within amorphous material of complex chemical composition ( $\alpha-1,3-$ glucan, $\beta$-1,3-glucan, glycoprotein). The chitin of the infection peg, substomatal vesicle, infection hypha and haustorial mother cell is covered completely with this amorphous material. These results show, that each infection structure has distinct surface and wall
\end{abstract}

* Correspondence and reprints: Lehrstuhl für Phytopathologie, Fakultät für Biologie, Universität Konstanz, D-W-7750 Konstanz, Federal Republic of Germany.

** Present address: Max-Planck-Institut für Züchtungsforschung, Abteilung für Biochemie, Köln, Federal Republic of Germany. characteristics. They may reflect the different tasks of the infection structures during host recognition and leaf penetration.

Keywords: Rust fungi; Uromyces; Infection structures; Lectins; Cell wall architecture.

Abbreviations: AP appressorium; FITC fluorescein isothiocyanate; GT germ tube; HC haustorial mother cell; IH infection hypha; IP infection peg; LCA Lens culinaris agglutinin; n nucleus; neu neuramic acid; $\mathrm{p}$ pyranoside; $\mathrm{R}$ ring; s septum; $\mathrm{SV}$ substomatal vesicle; WGA wheat germ agglutinin.

\section{Introduction}

The cell wall is responsible not only for fungal morphology, but also interacts with its environment. Fragments of fungal walls include oligosaccharins which function in plants as chemical messages with specific regulatory properties (Darvill et al. 1989, Habreder et al. 1989, Kessman and Barz 1986, Lamb et al. 1989). They may activate plant defense genes, suppress such responses or in the case of Nicotiana, even protect plants against infection by viruses (Kopp et al. 1989). Rust fungi develop a series of highly specialized infected structures in order to reach the plant mesophyll. The germ tube of the uredospore grows on the plant cuticle, recognizes the stoma and forms an appressorium over the guard cells (Hoch et al. 1987). From this appressorium, an infection peg penetrates the substomatal chamber and a substomatal vesicle develops. This structure elongates into the infection hypha and develops a haustorial mother cell at its tip.

Some rust fungi, e.g., Uromyces viciae-fabae produce these infection structures also on oil-containing col- 
lodion membranes in vitro. Isolation of single infection structures such as appressoria or infection hyphae has not yet been possible. Therefore, FITC-labelled lectins have been used to study the surface carbohydrates of such rust hyphae. Each infection structure, including haustoria, binds FITC-labelled lectins in a typical pattern (Mendgen et al. 1985, Heath 1989). Also the surface carbohydrate pattern changes during the development of appressoria (Kapooria and Mendgen 1985). Phenomena associated with initial stages of fungal contact on host surfaces may play a critical role in the success of infection (Kunoh et al. 1990).

It is not known how hydrolytic enzymes, which may also occur in the intercellular space of host plants (Fink et al. 1989), influence the fungus. Furthermore, the enzyme and alkali treatments reveal internal structural of hyphal cell walls (Hunsley and Burnett 1970). Typically the outer layers of the wall are soluble in dilute alkali leaving the inner layer as an insoluble residue. In Basidiomycetes, the alkali-soluble fraction contains $\alpha$-1,3-glucan, in a number of cases also fragments of $\beta-1,3 / 1,6-\mathrm{D}$-glucan, while alkali insoluble polymers are chitin and $\beta-1,3 / 1,6$-glucans (Wessels 1986).

We tested the changes in hyphal walls after enzyme and alkali treatment with FITC-labeled WGA and LCA. Low temperature replicas of infection structures before and after such treatments gave impressions of the ultrastructural architecture.

\section{Material and methods}

\section{Fungal material}

Uromyces viciae-fabae (Pers.) Schroet. on Vicia faba L. f, sp, "Con amor" was raised in a growth chamber under $16 \mathrm{~h}$ photoperiod (10,000 lux) approx. $70 \% \mathrm{RH}$, and $20^{\circ} \mathrm{C}$.

Fourteen-day-old plants were inoculated with a uredospore suspension $(10 \mathrm{mg} / 10 \mathrm{ml}$ tap water, containing $15 \mathrm{mg}$ Talcum) and incubated in the dark at $18-20^{\circ} \mathrm{C}$ and $100 \% \mathrm{RH}$ for $20-24 \mathrm{~h}$.

Uredospores were collected 14 days after inoculation and stored up to one week at $4^{\circ} \mathrm{C}$ before use. Collodion membranes containing 5 or $10 \mu 1 / \mathrm{ml}$ paraffin oil ( Wynn 1976) were floated on water and spread on agar before they were inoculated with uredospores in a settling

Table 1. Lectins, their specificity and inhibitory sugars (after Goldstein and Hayes 1978)

\begin{tabular}{llll}
\hline Lectin & Abbr. & Specificity & Inhibitory sugar \\
\hline Triticum vulgare & WGA & $\beta$-(D-1,4-GlcNAcp $)_{3}>$ & hydrolysate from chitin \\
& & $\beta-(\mathrm{D}-1,4-\mathrm{GlNNacp})_{2}$ \\
& NeuNAc & \\
Lens culinaris & $\alpha$-D-mannop $>$ & $\alpha$-D-methylmannopyranoside \\
& LCA & $\alpha$-glucop> \\
& & $\alpha$-D-glcNAcp & \\
\hline
\end{tabular}

Table 2. Conditions for enzyme experiments

\begin{tabular}{|c|c|c|}
\hline Enzyme & Origin & Buffer \\
\hline Chitinase & $\begin{array}{l}\text { Streptonyces griseus } \\
\text { (Sigma, C 6137) } \\
\text { EC 3.2.1.14 }\end{array}$ & $\begin{array}{l}5 \mathrm{mg} / \mathrm{ml} ; 2-3 \mathrm{U} / \mathrm{mg} \\
0.1 \mathrm{M} \mathrm{Na} \mathrm{HPO}_{4} / \mathrm{NaH}_{2} \mathrm{PO}_{4}, \\
\text { pH } 5.0\end{array}$ \\
\hline Pronase E & $\begin{array}{l}\text { Streptomyces griseus } \\
\text { (Sigma, P 5147) } \\
\text { EC 3.4.24.4 }\end{array}$ & $\begin{array}{l}0.5 \mathrm{mg} / \mathrm{ml} ; 4 \mathrm{U} / \mathrm{mg} \\
0.05 \mathrm{M} \operatorname{Tris} / \mathrm{HCl} ; \mathrm{pH} 7.5\end{array}$ \\
\hline $\begin{array}{l}\text { Laminarinase } \\
(1,3-(1,3 ; 1,4)-\beta-D \text {-glucan } 3(4) \text {-glucanhydrolase })\end{array}$ & $\begin{array}{l}\text { mollusc } \\
\text { (Sigma, L 7758) } \\
\text { EC 3.2.1.6 }\end{array}$ & $\begin{array}{l}5 \mathrm{mg} / \mathrm{ml} ; 10-30 \mathrm{U} / \mathrm{g} \\
0.01 \mathrm{M} \mathrm{KAc} ; \mathrm{pH} 5.0\end{array}$ \\
\hline $\begin{array}{l}\text { p-1,3-glucanase } \\
\text { (with } \alpha-1,3 \text {-glucanase and chitinase) }\end{array}$ & $\begin{array}{l}\text { Penicillium enersonii } \\
(\mathrm{BDH}, \mathrm{GB} ; 391202 \mathrm{G})\end{array}$ & $\begin{array}{l}\text { undiluted; } 1500 \mathrm{U} / \mathrm{ml} \\
0.1 \mathrm{M} \mathrm{KAc} ; \mathrm{pH} 5.0\end{array}$ \\
\hline $\begin{array}{l}\text { Lipase } \\
\text { (without protease-activity) }\end{array}$ & $\begin{array}{l}\text { pork (pancreas) } \\
\text { (Boehringer 644072) } \\
\text { EC 3.1.1.3 }\end{array}$ & 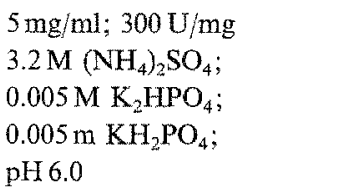 \\
\hline
\end{tabular}


tower. To promote germination and infection structure formation uredospores were incubated for $24 \mathrm{~h}$ at $20^{\circ} \mathrm{C}$ and $100 \%$ relative humidity in darkness.

Pieces of membranes $\left(0.5 \mathrm{~cm}^{2}\right)$ with infection structures were transferred to glass slides and histochemically treated.

\section{Histochemical procedures}

Nuclei and septa were stained with $5 \mu \mathrm{l} / \mathrm{m} /$ DAPI (4,6-diamidino2-phenylindole $\cdot 2 \mathrm{HCl}$, Serva, in $0.05 \mathrm{M}$ sodium phosphate buffer, $\mathrm{pH} 7.2$ for $5 \mathrm{~min}$ ) and $0.02 \%(\mathrm{w} / \mathrm{v})$ Calcofluor $[2 \mathrm{~min}$ after fixation in $2 \%(\mathrm{v} / \mathrm{v})$ glutaraldehyde for $20 \mathrm{~min}]$.

Fluorescence microscopy of inoculated host leaves was done using the method described by Rohringer et al. (1976).

Observations were made with a Zeiss Standatd incident fluorescence microscope. A $365 \mathrm{~mm}$ excitation filter and a $420 \mathrm{~nm}$ barrier filter were used.

For detection of carbohydrates, FITC-labeled lectins (Table 1) from Sigma were used in $0.01 \mathrm{M}$ sodium phosphate buffer with $0.15 \mathrm{M}$ $\mathrm{NaCl}, \mathrm{pH} 7.2$ (PBS). A drop of lectin in buffer $(0.1 \mathrm{mg} / \mathrm{ml})$ was placed on the membrane for $30 \mathrm{~min}$. After washing with buffer $(10 \times)$, the membrane was observed with the fluorescence microscope in glycerin/dest. water $(1: 1, \mathrm{v} / \mathrm{v})$. To inhibit lectin binding, $0.2 \mathrm{mg} / \mathrm{ml}$ of the inhibitory sugar was incubated with the lectin solution $(1: 1, v / v)$ for $30 \mathrm{~min}$ and afterwards placed on the membrane. The WGA-inhib- itory sugar was a chitin hydrolysate prepared according to Hankin and Anagnostakis (1975).

For the treatment with enzymes (Table 2), infection structures on collodion membranes were mounted on microscope slides. A $50 \mu l$ drop of enzyme solution was placed on the membrane and incubated for $20 \mathrm{~h}$ at $100 \% \mathrm{RH}$ and $37^{\circ} \mathrm{C}$. A treatment with sodium hydroxide (1 M) was performed for $30 \mathrm{~min}$ at $20^{\circ} \mathrm{C}$. After incubation, specimen were washed ten times with the appropriate buffer to the enzyme and labeled with lectins as described above.

The purity of some enzymes was tested with a colorimetric assay for reducing sugars and a radiometric assay for ${ }^{3} \mathrm{H}$-labeled chitin after Fink et al. (1988). The substrates used were chitin, $\beta$-1,3-glucan (laminarin), $\alpha-1,3 / 1,4$-glucan (nigeran $1 \mathrm{mg} / \mathrm{ml}$ ), $\beta-1,3 / 1,6$-glucan (yeast glucan $1 \mathrm{mg} / \mathrm{ml}$ ), $\alpha$-1,4-glucan (starch $1 \mathrm{mg} / \mathrm{ml}$ ) and $\alpha-1,3$-glucan $(1 \mathrm{mg} / \mathrm{ml})$. The $\alpha-1,3$-glucan was a gift of Prof. Dr. J. G. H. Wessels, Rijksuniversiteit Groningen, Netherlands.

Laminarinase contained $890 \mathrm{pkat} / \mathrm{mg}$ protein $\beta-1,3$-glucanase activity, $44 \mathrm{pkat} / \mathrm{mg}$ protein $\alpha-1,3$-glucanase activity and $140 \mathrm{cpm} / \mathrm{h} / \mathrm{mg}$ protein chitinase activity.

The $\beta$-1,3-glucanase contained 143,200 pkat/mg protein $\beta$-1,3-glucanase activity and $61,200 \mathrm{pkat} / \mathrm{mg}$ protein $\alpha-1,3$-glucanase activity and $177,000 \mathrm{cpm} / \mathrm{h} / \mathrm{mg}$ protein chitinase activity.

Chitinase contained $28 \mathrm{pkat} / \mathrm{mg}$ protein $\beta-1,3$-glucanase acitivity and $60,800 \mathrm{cpm} / \mathrm{h} / \mathrm{mg}$ protein chitinase activity. Protease contained
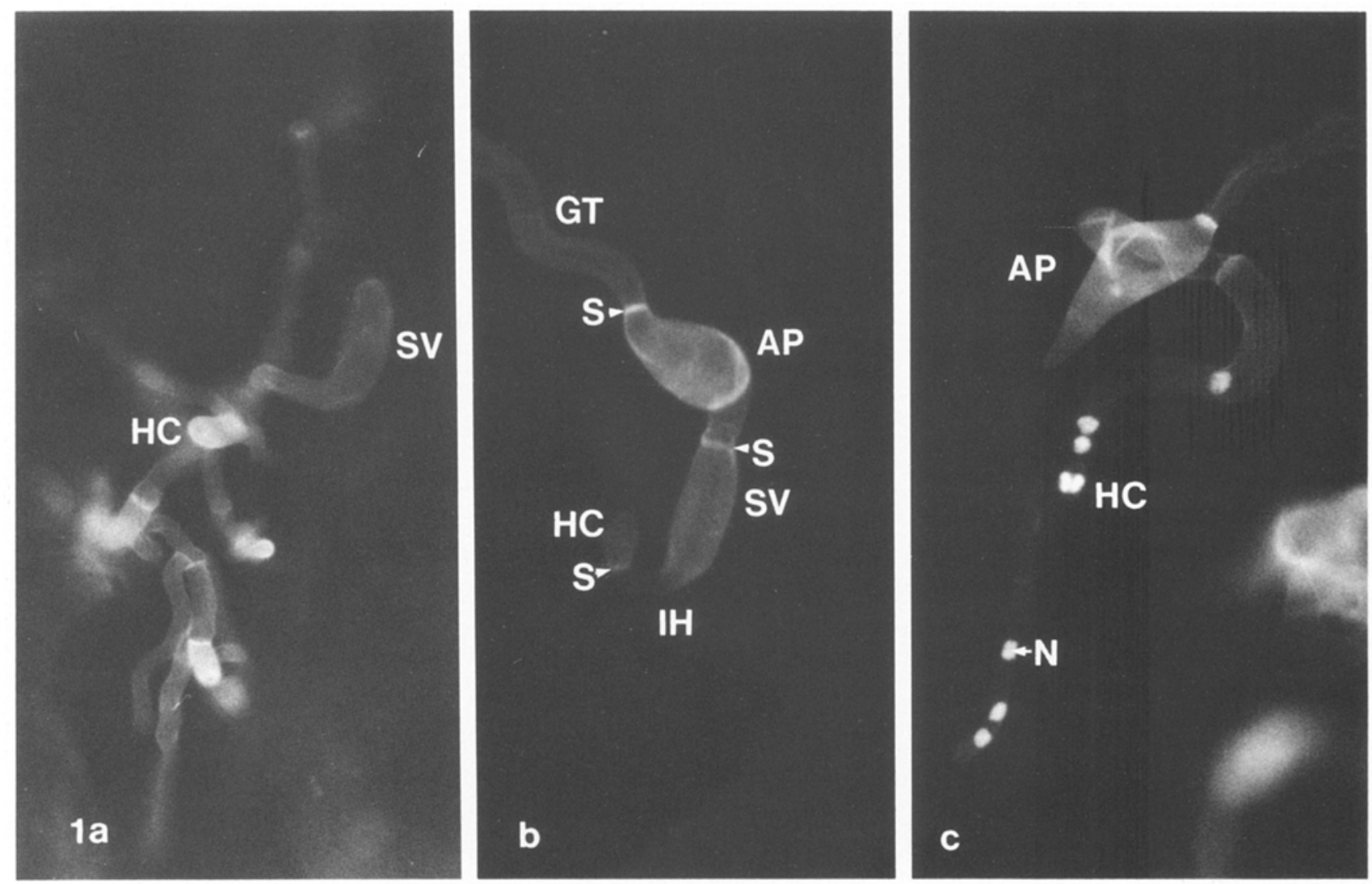

Fig. 1. a Uredospore infection structures of Uromyces viciae-fabae. After staining with diethanol, the substomatal vesicle, infection hypha, secondary hypha and haustorial mother cell become visible within the plant. Germ tube and appressorium on the cuticle are out of focus $(\times 500)$. b On the membrane, the fungus generally stops growing after haustorial mother cell formation. Calcofluor stains walls and septa $(\times 500)$. $\mathrm{c}$ Nuclear distribution in infection structures and the first-formed secondary hypha (DAPI and Calcofluor staining). The haustorial mother cell has four nuclei, which are difficult to discern $(\times 500)$ 
$47 \mathrm{pkat} / \mathrm{mg}$ protein laminarinase activity and $4,500 \mathrm{cpm} / \mathrm{h} / \mathrm{mg}$ chi tinase activity.

For microscope photometry, a Leitz microscope photometer, equipped with a $100 \mathrm{~W}$ mercury lamp for epiffuorescence was used with an automatic shutter system allowing measuring times of $0.25 \mathrm{~s}$. The instrument was standardized to give a scale from 0 - 100 by using a measuring diaphragm of $2.2 \times 10 \mu \mathrm{m}$ and (a) a fluorescence standard (uranylglas GG 17 , from Zeiss, Oberkochen) or (b) $25 \mu \mathrm{M}$ fluorescein diacetate solution in a chamber of $0.1 \mathrm{~mm}$ thickness, prepared after Jongsma et al. (1971). It was focussed on a sharp gold edge on the cover slip.

The $100 \times$, n.a. 1.3 oil immersion lens was used with the 12 -fluorescence filter set (BP 450-490; RKP 510; LP 515). Ten to twenty infection structures of each variant were measured. As controls, infection structures were measured with lectins inhibited with an appropriate sugar (Table 1), and in buffer alone.

\section{Replica procedure}

To obtain the replica from infection structures, collodion membranes were dipped quickly into liquid propane and transferred into liquid nitrogen. After freeze-drying at $-80^{\circ} \mathrm{C}$ in the Edwards coating unit E 306 , the samples were shadowed with carbon/platinum at $-80^{\circ} \mathrm{C}$ and an angle of $30^{\circ} \mathrm{C}$. Samples for comparison were dried and shadowed at room temperature.

The replicas were cleaned at room temperature in $0.25 \mathrm{M}$ chromic acid for approximately $30 \mathrm{~min}$. After washing in distilled water, they were mounted on pioloform-coated grids and examined with a Zeiss EM $10 \mathrm{C}$ transmission electron microscope.

\section{Results}

\section{Cytology of the in vitro induced infection structures}

On collodion membranes with paraffin oil inclusions, uredospores of Uromyces viciae-fabae developed a series of infection structures (germ tube, appressorium, infection peg, substomatal vesicle, infection hyphae and haustorial mother cell). At $24 \mathrm{~h}$ after inoculation, about $22 \%$ of the germlings had produced haustorial mother cells. Stained with diethanol, the morphology of the artificially induced infection structures was similar to infection structures differentiated in host tissue (Fig. $1 \mathrm{a}$ and b). Appressoria and haustorial mother cells fluoresced more intensively than other infection structures.

Five percent of all haustorial mother cells had two nuclei, $41 \%$ had four nuclei, $13 \%$ five and $7 \%$ had six nuclei. In $22 \%$ of the haustorial mother cells, the number of the nuclei was not discernible (Fig. 1 c). Sometimes a non-fluorescent dark spot could be seen in the wall of the haustorial mother cell (Fig. 2 a).

\section{Lectin binding to cell walls before and after treatment with enzymes or inorganic solvents}

The lectin WGA bound to germ tubes and appressoria, but only faintly to infection pegs, substomatal vesicles, infection hyphae and haustorial mother cells (Figs. 2 a and 5). After incubation with LCA, substomatal vesicles, infection hyphae and haustorial mother cells exhibited more fluorescence than germ tubes and appressoria (Fig. 6). Binding of the FITC-labelled lectins WGA and LCA to the untreated infection structures was successfully inhibited by specific sugars (Table 1). To study the chemical compostion of cell walls, uredospore infection structures were treated with different hydrolytic enzymes and/or inorganic reagents. Subsequently the binding rate of the two lectins was determined semiquantitatively with the microscope photometer. After a $20 \mathrm{~h}$ incubation period, the enzymes changed the binding pattern of WGA to the infection structures considerably (Figs. 5 and 6). In contrast, treatment of the various infection structures with chitinase resulted in no more than a barely detectable change in the pattern of fluorescence (data not shown). There was no visible difference in the reaction to the treatments between hyphae and hyphal tips.

After treatment with pronase $\mathrm{E}$, the binding rate of WGA to the germ tube, appressorium and haustorial mother cell increased (Fig. 5). Treatment of the haustorial mother cell wall with pronase $\mathrm{E}$ revealed the presence of a structure in the form of a brightly fluorescent ring (Fig. 2 b).

Pronase $\mathrm{E}$ treatment did not reveal additional binding sites for LCA-FITC, but reduced lectin binding to the substomatal vesicle, infection hypha and haustorial mother cell (Fig. 6). Lipase treatment exposed binding sites at all infection structures. The effect was more prominent with the substomatal vesicle, the infection hypha and the haustorial mother cell.

After treatment with laminarinase, the binding pattern of WGA depended on the concentration of the enzyme used. With low concentration $(0.5 \mathrm{mg} / \mathrm{ml})$ the binding to appressoria and germ tubes increased (data not shown). After application of a higher concentration $(5 \mathrm{mg} / \mathrm{ml})$, WGA binding to appressoria increased even more strongly (Fig. 5). However, fluorescence intensity of the other infection structures remained unchanged (Fig. 2 d). After this treatment and subsequent incubation with LCA, receptors for this lectin were disclosed everywhere (Fig. 6).

A mixture of $\alpha$-1,3- and $\beta$-1,3-glucanase which also included some chitinase activity dissolved the germ tube and the appressorium completely. The infection peg with the substomatal vesicle, the infection hypha and the haustorial mother cell remained and exhibited more intensive fluorescence after incubation with WGAFITC (Figs. 2e, f and 5). 
After treatment with a sodium hydroxide solution and subsequent incubation with WGA-FITC, the walls of all infection structures (Fig. 2c) fluoresced, with the exception of the germ tube, with much higher intensity than prior to treatment (Fig. 5).
When the treatment with sodium hydroxide was followed by incubation with chitinase or laminarinase, different results were obtained (Fig. 5). The subsequent laminarinase treatment revealed numerous binding sites for WGA on appressoria and haustorial mother
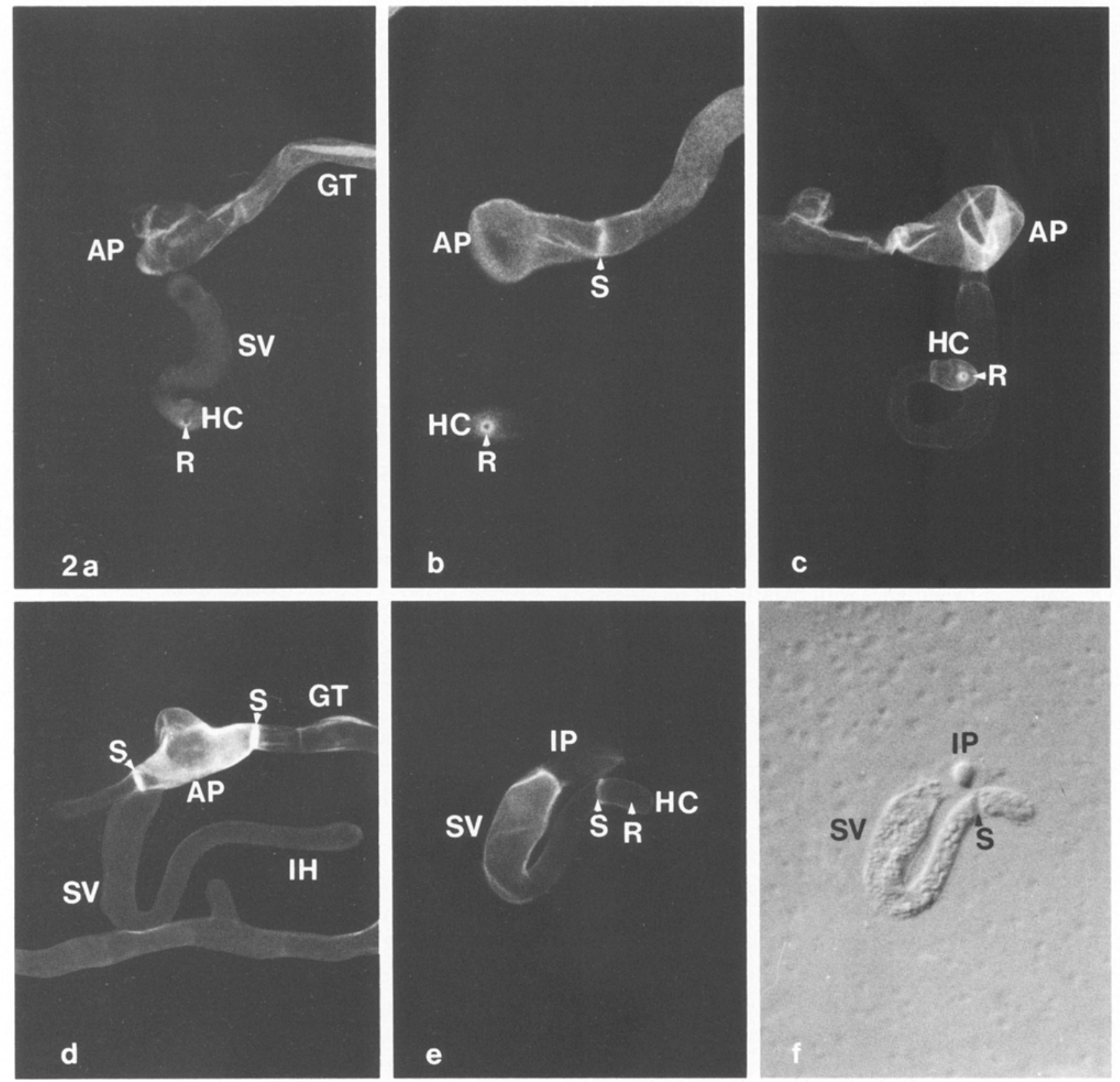

Fig. 2. a Before any treatment, WGA-FITC binds mainly to germ tubes and appressoria of Uromyces viciae-fabae, but also faintly to haustorium mother cells. A dark spot in the haustorium mother cell wall is possibly the penetration peg $(\times 500)$. b Treatment with protease increased binding of WGA to germ tubes and appressoria considerably. On the wall of the haustorium mother cell, a ring that surrounds the dark spot ( $\mathrm{cf}$ a) binds heavily to WGA $(\times 900)$. c After treatment with sodium hydroxide, the infection structures exhibit overall binding with WGA. A ring around the penetration peg is obvious $(\times 670)$. d Treatment with laminarinase resulted in binding of WGA to the appressorium, but not to the germ tube $(\times 670)$. e Treatment with an enzyme mixture $(\alpha-1,3-$ and $\beta-1,3-g l u c a n a s e)$ dissolves the germ tube and the appressorium completely. Infection peg, substomatal vesicle, infection hypha and haustorial mother cell remain and the remnants bind to WGA. I Same as $\mathbf{e}$, in interference contrast $(\times 500)$ 
cells, few on the infection hyphae. The subsequent treatment with chitinase revealed no additional binding sites.

\section{Ultrastructure of untreated and treated cell walls of the infection structures}

Freshly frozen, untreated infection structures were well preserved after freeze drying and shadowing at $-80^{\circ} \mathrm{C}$. The surface of germ tubes and infection hyphae differed considerably. Only the germ tube exhibited ends of fibrils, which seemed to reach out of the amorphous surface (Fig. $3 \mathrm{a}$ and $\mathrm{b}$ ). The surface of the infection hypha appeared more or less smooth but interspersed with many depressions (Fig. $3 \mathrm{c}$ and d).

Treatment of germ tubes with protease revealed microfibrils embedded in an amorphous material (Fig. 4 a). After treatment with laminarinase, more fibrils were disclosed and the amorphous material seemed completely removed (Fig. 4 b). This effect was less pronounced after treatment with sodium hydroxide (Fig. $4 \mathrm{c}$ ). During drying at room temperature, the amorphous material seemed to collapse and the fibrils became much more evident (Fig. $4 \mathrm{~d}$ ).

The surface of the substomatal vesicle did not change substantly after treatment with protease (Fig. 4 e). The surface became rough after laminarinase treatment (Fig. 4 f) and only the treatment with sodium hydroxide disclosed some fine fibrils within an amorphous matrix (Fig. $4 \mathrm{~g}$ ).

\section{Discussion}

Germ tubes and appressoria of infection structures of rust fungi are characterized by a high affinity for WGA (Mendgen et al. 1985, Kapooria and Mendgen 1985, Heath 1989). This lectin may bind to the small fibrils that reach out of the amorphous coat.

Chitin has already been detected in germ tubes of rust fungi with other methods (Trocha and Daly 1974, Joppien 1976, Karminsky and Heath 1983). Also, cross sections exhibited chitin in the walls of Phakopsora pachyrhizi (Ebrahim-Nesbat et al. 1985) and Puccinia graminis (Chong et al. 1985, Harder et al. 1986). This chitin seems to be mixed with $\beta$-1,3-glucans, $\alpha-1,3-$ glucans and proteins. Glycoproteins were described first for germ tubes of Puccinia graminis, together with mannose, galactose, fucose, glucose, ribose and rhamnose (Kim et al. 1982). They can be removed with protease. The chitin seems to be covalently bound with $\beta$ glucans (Wessels 1986) and also with $\alpha$-glucans, since the mixture of $\alpha$-and $\beta$-glucanase dissolved germ tubes and appressoria completely. We do not know how much the impurities of the enzyme, such as chitinase, add to this effect. The high values of WGA-FITC fluorescence of the appressorium suggest that the latter has a higher chitin content.
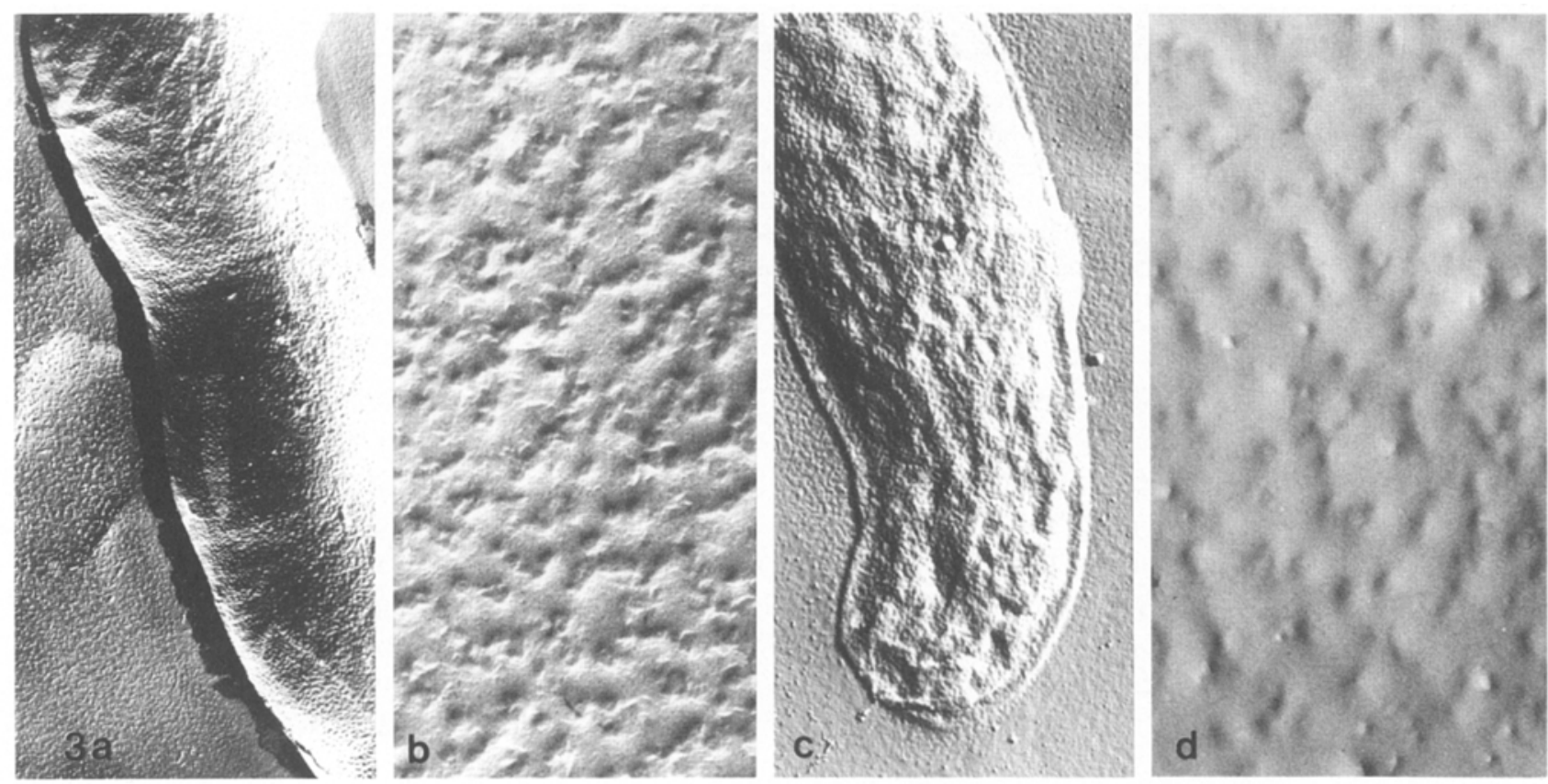

Fig. 3. The untreated surface of a germ tube $(\mathbf{a}, \mathbf{b})$ and an infection hypha $(\mathbf{c}, \mathbf{d})$ of Uromyces viciae-fabae. Ends of fibrils reach out of the amorphous material of the germ tube. $a, c: \times 5,000 ; b, d: \times 38,000$ 

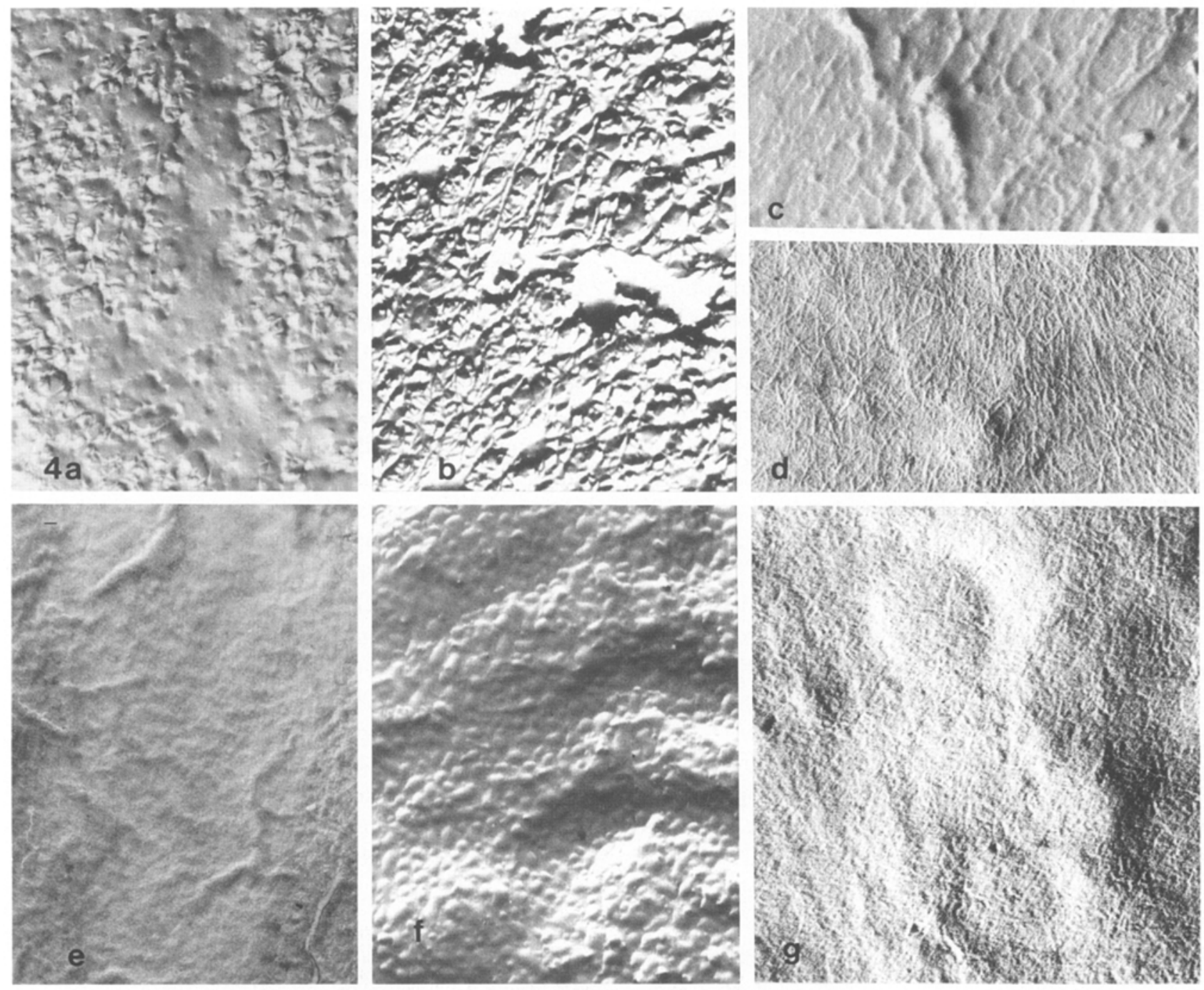

Fig. 4. The ultrastructure of the surface of the germ tube (a-d) and substomatal vesicle (e-g) of Uromyces viciae-fabae after treatment with protease, laminarinase and sodium hydroxide. In the cell wall of the germ tube, fibrils become visible under the amorphous layer after protease (a) and laminarinase (b) treatment. After treatment with sodium hydroxide, a network of fine interwoven fibrils is uncovered on the infection structure. Depending on the penetration method, the fibrils appear as a dense network after drying and shadowing at $20^{\circ} \mathrm{C}(\mathrm{d}$ and $\mathrm{g}$ ), or even more delicate after freeze-drying and shadowing at $-80^{\circ} \mathrm{C}$ (c). The surface of the substomatal vesicle remains rough after treatment with protease (e) and laminarinase (f). When treated with sodium hydroxide, a dense fibrillar network appears (g). a-g: $\times 38,000$

The structure of germ tubes and appressoria appears to correlate with the function of the morphological stages of development. Glycoproteins or proteins play a major role in adhesion of germ tubes to the host surface and may be responsible for the recognition of the stomatal lip that induces appressorium formation (Epstein et al. 1985). The glycoproteins or parts thereof can elicit unspecific defense reactions in plants (Kogel etal. 1988, Moerschbacher et al, 1988). The appressorium may need a thick wall with high chitin content to resist the high turgor pressure, obviously essential for infection of the host cell (Howard and Ferrari 1989).
Some rusts, e.g., Phakopsora pachyrhizi (Koch etal. 1983), penetrate from their appressoria directly into epidermal cells necessitating that their appessoria are capable of withstanding high turgor pressures.

The cell wall architecture of the substomatal vesicle and the infection hypha is quite different from that of the earlier infection structures. These structures appear to be covered with $\alpha-1,3$-glucans and $\beta$-1,3-glucans on their surfaces, but their treatment with glucanases did not reveal a substantial amount of underlying chitin. This effect is even more pronounced over the infection hypha. Also, the electron microscope reveals no evi- 

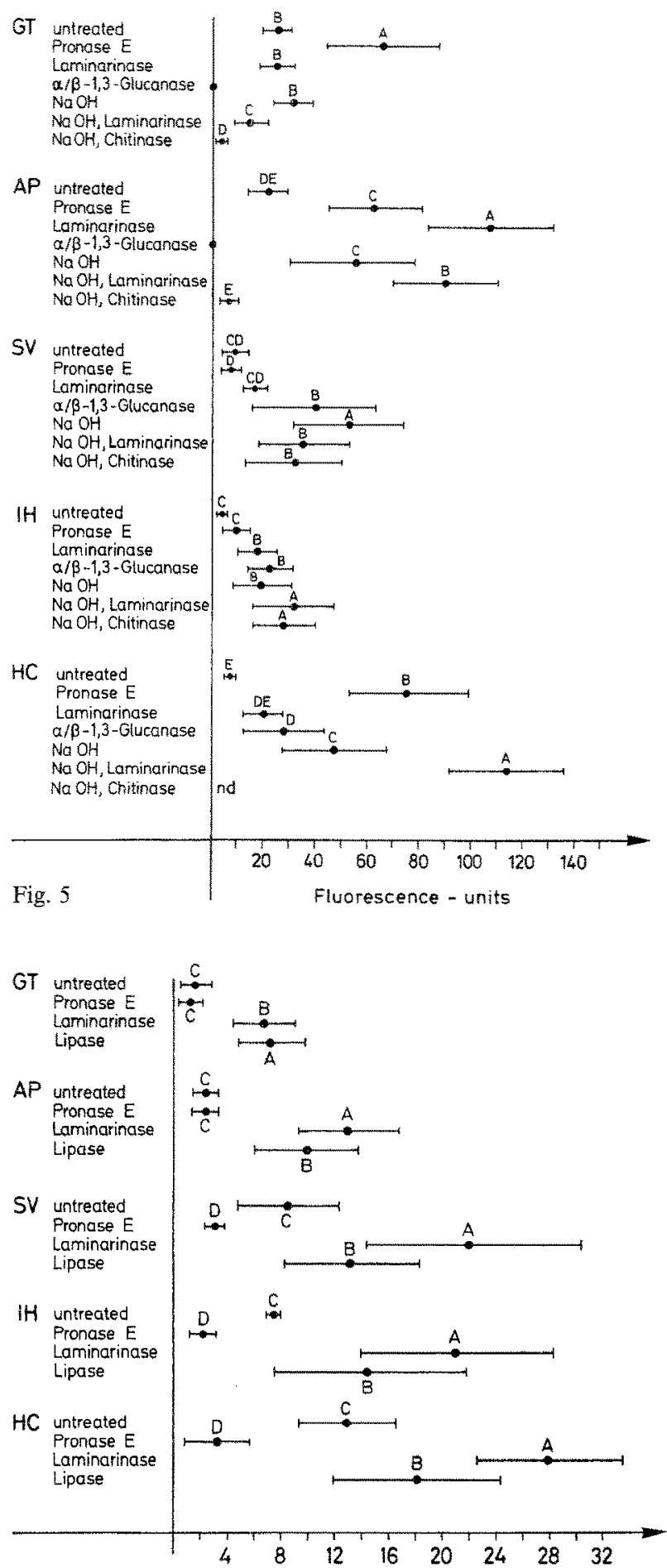

Fig. 6

Fluorescence - units

Figs. 5 and 6. Fluorescence intensity of the FITC-labeled lectins WGA and LCA on in vitro induced infection structures of Uromyces viciae-fabae after treatment with enzymes and/or sodium hydroxide. The means (points) are the average of 10-15 infection structures measured for each treatment. The standard deviation is indicated as bar. Data were analysed with Duncan's Multiple Range test referring to each infection structure. Means with the same letters indicate no statistic difference (confidence interval 95\%) dence for chitin on substomatal vesicles after protease and laminarinase treatment. The surface remains relatively smooth and no fibrillar structure is exposed. The weak binding of WGA contrasts with a very obvious binding to LCA after treatment with laminarinase and lipase suggesting a layer with high affinity to LCA. This layer covering the chitin in the walls of substomatal vesicles and infection hyphae seems to consist of glycoproteins as the major constituent since it is protease sensitive and LCA positive. Only treatment with sodium hydroxide or hot hydrochloric acid (result not shown) removed this layer and revealed the chitin skeleton which was already demonstrated in other cytochemical studies (Karminsky and Heath 1983, Chong et al. 1985).

The haustorial mother cell has some similarities to the appressorium. It also has a very dense inner chitin layer as indicated by its high affinity to WGA after removal of the outer mucilage with pronase $\mathrm{E}$ or sodium hydroxide followed by laminarinase. Results obtained previously but using different methods (Karminsky and Heath 1983, Heath and Perumalla 1989) support the conclusion, that appressoria and haustorial mother cells have structural similarities. A thick chitin layer may reflect the need to resist high turgor pressure during penetration of the host. The chitin is covered with LCA positive glycoproteins, which can be removed by pronase E treatment. This latter layer seems to be covered by a layer of glucans that are removeable by treatment with lipase and laminarinase.

Our studies cannot prove the existence of discrete layers in hyphae. Burnett (1979) pointed out that the coaxially arranged layers are not discrete but grade into each other. Recent observation obtained from cross sections through hyphae of Puccinia graminis (Harder et al. 1986, 1989) and Uromyces appendiculatus (Welter et al. 1988) support a layered structure. In these studies, hyphae are characterized by a main wall covered with a more or less fibrillar mucilage, which is often deposited in layers. At each growth stage, the layering of walls and mucilage is different. Even during growth of the fungus within the leaf tissue, the number of layers (Welter etal. 1988) or their composition, as shown after application of lectins, may change (Harder et al. 1989). It seems that the model of the hyphal wall for Schizophyllum commune (Wessels and Sietsma 1981) and Agaricus bisporus (Michalenko et al. 1976) is relevant also for rust fungi. An alkali insoluble chitin/ $\beta-1,3-$ glucan complex, with fibrillar structure, is embedded in, and covered by, an amorphous gel-like material rich in $\beta-1,3 / \beta-1,6$-glucans and $\alpha-1,3$-glucans. In addition 
glycoproteins with different glycosyl and fucosyl residues are mixed with these former constituents or form more or less discrete layers.

The application of enzymes for the digestion of infection structures has added further evidence for the quite abrupt change in structure from the appressorium to the substomatal vesicle. This seems to indicate that substantial changes in wall chemistry occur as a normal morphological ontogeny event. There is also evidence that a similar phenomenon occurs during differentiation of the penetration peg and the haustorium (Heath 1989).

The meaning of this very complex wall structure, which is also obvious in cross sections (Chong et al. 1985, Heath and Heath 1975) is still unknown. Perhaps that the very special mixture of surface carbohydrates is responsible for a signalling between host and parasite and may prepare the host cell for the subsequent establishment of the haustorium (Mendgen 1988).

\section{Acknowledgements}

We thank M. Liefland for help with the chitinase assay and Dr. W. Fink, Dr. H. Deising and Prof. Dr. R. L. Nicholson for valuable discussions and critically reading of this manuscript. This research was supported by the Deutsche Forschungsgemeinschaft (Me 523-13).

\section{References}

Burnett JH (1979) Aspects of the structure and growth of hyphal walls. In: Burnett JH, Trinci APJ (eds) Fungal walls and hyphal growth. Cambridge University Press, London, pp 2-25

Chong J, Harder DE, Rohringer R (1985) Cytochemical studies on Puccinia graminis f. sp. tritici in a compatible wheat host. I. Walls of intercellular hyphal cells and haustorial mother cells. Can J Bot 63: 1713-1724

Darvill AG, Albersheim P, Bucheli S, Doares N, Doubrava S, Gollin DJ, Hahn MG, Marfä-Riera V, York WS, Mohnen D (1989) Oligosaccharins-plant regulatory molecules. In: Lugtenberg BJJ (ed) Signal molecules in plants and plant-microbe interactions. Springer, Berlin Heidelberg New York Tokyo, pp 41-49 [NATO ASI series $H$, vol 36]

Ebrahim-Nesbat F, Hoppe HH, Rohringer R (1985) Lectin binding studies on the cell walls of soybean rust (Phakopsora pachyrhizi Syd.). Phytopathol Z 114:97-107

Epstein L, Lacetti L, Staples RC, Hoch HC, Hoose WA (1985) Extracellular proteins associated with induction of differentiation in bean rust uredospore germlings. Phytopathology 75 : 1073-1076

Fink W, Liefland M, Mendgen K (1988) Chitinase and $\beta$-1,3-glucanases in the apoplastic compartment of oat leaves (Avenasativa L.). Plant Physiol 88: 270-275

Goldstein II, Hayes CE (1978) The lectins: carbohydrate-binding proteins of plants and animals. Adv Carbohydr Chem Biochem 35: $127-340$

Habreder H, Schröder $\mathbf{G}$, Ebel J (1989) Rapid induction of phenylalanine ammonia-lyase and chalcone synthase mRNAs during fungus infection of soybean (Glycine max.) roots or elicitor treatment of soybean cell cultures at the onset of phytoalexin synthesis. Planta 177: 58-65

Hankin L, Anagnostakis SL (1975) The use of solid media for detection of enzyme production by fungi. Mycologia 67: 597-607

Harder DE, Chong J, Rohringer R, Kim WF (1986) Structure and cytochemistry of the walls of uredospores, germ tubes and appressoria of Puccinia graminis tritici. Can J Bot 64: 476-485

- - - Mendgen K, Schneider A, Welter K, Knauf G (1989) Ultrastructure and cytochemistry of extramural substances associated with intercellular hyphae of several rust fungi. Can $\mathbf{J}$ Bot 67: 2040-2051

Heath MC (1989) In vitro formation of haustoria of the cowpea rust fungus, Uromyces vignae, in the absence of a living plant cell. I. Light microscopy. Physiol Mol Plant Pathol 35: 357-368

- Heath B (1975) Ultrastructural changes associated with the haustorial mother cell septum during haustorium formation in Uromyces phaseoli var. vignae, Protoplasma 84: 297-314

- Perumalla CJ (1988) Haustorial mother cell development by Uromyces vignae on collodion membranes. Can J Bot 66: 736-741

Hoch HC, Staples RC, Whitehead B, Comeau J, Wolf ED (1987) Signalling for growth orientation and cell differentiation by surface topography in Uromyces. Science 235: 1659-1662

Howard RJ, Ferrari MA (1989) Role of melanin in appressorium function. Exp Mycol 13: 403-418

Hunsley D, Burnett JH (1970) The ultrastructural architecture of the walls of some hyphal fungi. J Gen Microbiol 62: 203-218

Jongsma APM, Hijmans E, Ploem JS (1971) Quantitative immunofluorescence standardization and calibration in microfluorometry. Histochemie 25: $329-343$

Joppien S, Burger A, Reisener HJ (1972) Untersuchungen über den chemischen Aufbau von Sporen- und Keimschlauchwänden der Uredosporen des Weizenrostes (Puccinia graminis var. tritici). Arch Microbiol 82:337-352

Kapooria RG, Mendgen K (1985) Infection structures and their surface changes during differentiation in Uromyces fabae. Phy topathol Z 113: $317-323$

Karminsky SGW, Heath MC (1983) Histological responses of infection structures and intercellular mycelium of Uromyces phaseoli var. typica and $U$. phaseoli var. vignae to the $\mathrm{HNO}_{2}-\mathrm{MBTH}$ $\mathrm{FeCl}_{3}$ and the IKI- $\mathrm{H}_{2} \mathrm{SO}_{4}$ tests. Physiol Plant Pathol 22: 173-179

Kessmann H, Barz W (1986) Elicitation and suppression of phytoalexin and isoflavone accumulation in cotyledons of Cicer arietinum L. as caused by wounding and by polymeric components from the fungus Ascochyta rabiei. J Phytopathol 117: 321-335

Kim WK, Rohringer R, Chong J (1982) Sugar and amino acid composition of macromolecular constituents released from walls of uredosporelings of Puccinia graminis tritici. Can J Plant Pathol 4: $317-327$

Koch E, Ebrahim-Nesbat F, Hoppe HH (1983) Light and electron microscopic studies on the development of soybean rust (Phakopsora pachyrhizi Syd.) in susceptible soybean leaves. Phytopathol Z 106: 302-320

Kogel G, Beissmann B, Reisener HJ, Kogel KH (1988) A single glycoprotein from Puccinia graminis f. sp. tritici cell walls elicits the hypersensitive lignification response in wheat. Physiol Mol Plant Pathol 33: 173-185

Kopp M, Rouster I, Fritig B, Darvill A, Albersheim P (1989) Host-pathogen interactions XXXII. A fungal glucan preparation protects Nicotianae against infection by viruses. Plant Physiol 90: 208-216 
Kunoh H, Nicholson RL, Kobayashi I (1990) Extracellular materials of fungal structures: their significance at prepenetration stages of infection. In: Mendgen $\mathrm{K}$, Lesemann DE (eds) Electron microscopy of plant pathogens. Springer, Berlin Heidelberg New York Tokyo, pp 223-234

Lamb CJ, Lawton MA, Dron M, Dixon RA (1989) Signals and transduction mechanisms for activation of plant defenses against microbial attack. Cell 56:215-224

Michalenko GO, Hohl HR, Rast D (1976) Chemistry and architecture of the mycelial wall of Agaricus bisporus. J Gen Microbiol 92: 251-262

Mendgen K, Lange M, Bretschneider K (1985) Quantitative estimation of the surface carbohydrates on the infection structures of rust fungi with enzymes and lectins. Arch Microbiol 140: 307-311

- Schneider A, Sterk M, Fink W (1988) The differentiation of infection structures as a result of recognition events between biotrophic parasites and their hosts. J Phytopathol 123: 259-272

Moerschbacher BM, Noll UM, Flott BE, Reisener HJ (1988) Lignin biosynthetic enzymes in stem rust infected resistant and suscep- tible near-isogenic wheat lines. Physiol Mol Plant Pathol 33: 33-46

Rohringer R, Kim WK, Samborski DJ, Howes NK (1976) Calcofluor: an optical brightener for fluorescence microscopy of fungal plant parasites in leaves. Phytopathology 67: 808-810

Trocha P, Daly JM, Langenbach LJ (1974) Cell walls of germinating uredospores II. Carbohydrate polymers. Plant Physiol 53: 527-536

Welter K, Müller M, Mendgen K (1988) The hyphae of Uromyces appendiculatus within the leaf tissue after high pressure freezing and freeze substitution. Protoplasma 147: 91-99

Wessels JGH (1986) Cell wall synthesis in apical hyphal growth. Int Rev Cytol 104: 37-78

- Sietsma JH (1981) Fungal cell walls: a survey. In: Tanner W, Loewus FA (eds) Plant carbohydrates II: extracellular carbohydrates. Springer, Berlin Heidelberg New York, pp $27-48$

Wynn WK (1975) Appressorium formation over stomates by the bean rust fungus: response to a surface contact stimulus. Phytopathology 66 : $136-146$ 